\title{
How to Return the Death Programs of Cancer Cells to Work again and Cure Cancer within a Short Time?
}

\author{
Mahmoud Saad Mohamed El-Khodary ${ }^{1,2}$, Sahar Ezeldien Hasan ${ }^{3}$, Wael A. Hassan ${ }^{4,5}$, \\ Maather M. El-Lamie6, Ismail A. M. Eissa6, Waleed F. Khalil'3, Salah M. Aly7 \\ ${ }^{1}$ Suez Canal University, Ismailia, Egypt \\ ${ }^{2}$ General Organization for Export and Import Control, Suez, Egypt \\ ${ }^{3}$ Pharmacology Department, Faculty of Vet. Medicine, Suez Canal University, Ismailia, Egypt \\ ${ }^{4}$ Pathology Department, Faculty of Medicine, Suez Canal University, Ismailia, Egypt \\ ${ }^{5}$ Department of Basic Sciences, Suliman Al-Rajhi Collage of Medicine, Al Bukayriyah, KSA \\ ${ }^{6}$ Department of Fish Diseases \& Management, Faculty of Vet. Medicine, Suez Canal Univ. Ismailia, Egypt \\ ${ }^{7}$ Pathology Department, Faculty of Vet. Medicine, Suez Canal University, Ismailia, Egypt \\ Email: surataljomaa@gmail.com, saharezeldien@gmail.com, W.Hassan@Sr.edu.sa, maather76@yahoo.com, \\ eissavet29@yahoo.com,wk@vet.suez.edu.eg, salahaly@hotmail.com
}

How to cite this paper: El-Khodary, M.S.M., Hasan, S.E., Hassan, W.A., El-Lamie, M.M., Eissa, I.A.M., Khalil, W.F. and Aly, S.M. (2019) How to Return the Death Programs of Cancer Cells to Work again and Cure Cancer within a Short Time? CellBio, 8, 17-39.

https://doi.org/10.4236/cellbio.2019.82002

Received: May 15, 2019

Accepted: June 27, 2019

Published: June 30, 2019

Copyright $\odot 2019$ by author(s) and Scientific Research Publishing Inc. This work is licensed under the Creative Commons Attribution International License (CC BY 4.0).

http://creativecommons.org/licenses/by/4.0/

\begin{abstract}
Cancer is cell fleeing from death by blocking the intrinsic and extrinsic pathways of cell death programs. In the present work, the experimental formula was designed to remove these blockers. It was applied on 120 Swiss albino mice which were inoculated intraperitoneally and subcutaneously with Ehrlich Ascites Carcinoma cells; $1 \times\left(10^{6}\right)$ cell/mouse. The activity of the cell death programs of the tumor was detected by measuring the volume of Ascites fluid, counting the number of dead cancer cells, measuring the size of the tumor, detecting the positive reaction of caspase enzyme in cancer cells and presence of macrophages and apoptotic bodies in tumor tissue. The experimental formula succeeded in removing the blockers of the cell death program in cancer cells returning the cell death program to work again.
\end{abstract}

\section{Keywords}

Cancer, Therapeutic Strategy, Accumulation, Detoxification Enzymes, Free Radicals, Antioxidants, $\mathrm{H}_{2} \mathrm{O}_{2}$, Glutathione, NF-kB, Sulforaphane, Flavonoid, Cur Cumin

\section{Introduction}

Cancer is a serious problem; it is more dangerous than nuclear bombs [1]. The 
World Health Organization in 2015 reported that 8.8 million people around the world died from cancer. In 2017, more than 14 million new cases were reported globally and may rise to over 21 million cases by 2030 [2] [3]. In (2018), 9.6 million deaths were recorded globally [4]. There are many types of cancer treatments like surgery, radiation, monoclonal therapy, adoptive cell transfer, target therapy, an angiogenesis inhibitor, hormone therapy, stem cell transplant and gold nanoparticles [5]. But for all types of treatment out there, they all have serious side effects and they are unable to save all cancer patients. Cancer is difficult to treat.

One of the protective mechanisms in a normal cell is its ability to flee from death; whenever there is damage to its DNA, to save its life [6]. During carcinogenesis, the cell acquires the ability to "shut down" apoptosis.

For the normal cell to become cancerous, it passes through four stages of transformation: accumulation stage, detoxification stage, free radical stage; especially superoxide free radicals and hydrogen peroxide production and nuclear factor kappa-b (NF-kB) activation stage [7]. The NF-kB is responsible for the production of six elements (muc-1, muc-4, muc-16, Bcl2, MMPs, and DcR3), which are used by cells to block the intrinsic and extrinsic programs of cell death, leading to carcinogenesis [8].

Therefore, if such blockers for cell death were removed, apoptosis pathways would be activated and cancer cells would succumb to death. To remove such blockers, we must stop the four stages of transformation until the activation of the NF-Kb stage to prevent the shutting down of the intrinsic and extrinsic programs of cell death. Shutting down one stage completely will be sufficient to stop the malignant transformation while shutting down all stages is the most comprehensive therapeutic strategy for treatment success [7].

We adopted the following strategy to remove all blockers of death programs (intrinsic and extrinsic): removing the carcinogenic substances out of the cell, regulating the levels of detoxification phase-I enzymes, scavenging the free radicals especially oxygenate origin, as superoxide free radicals and hydrogen peroxide, and keeping the NF-kB in inactive forms. The present study aimed to stimulate the death programs of cancer cells to work again and cure cancer within a short period using plants extract.

\section{Materials \& Methods}

\subsection{Experimental Formula}

Broccoli extract $3.4 \mathrm{mg} / \mathrm{mouse}$, Apple extract $14 \mathrm{mg} / \mathrm{mouse}$, Grape fruit extract 6 $\mathrm{mg} /$ mouse, blue berry $4 \mathrm{mg} /$ mouse, Turmeric extract $2 \mathrm{mg} /$ mouse, Vitamin A 3 $\mathrm{mg} /$ mouse, Vitamin C $3 \mathrm{mg} / \mathrm{mouse}$, Vitamin-E $3 \mathrm{mg} / \mathrm{mouse}$, Glutathione 0.4 $\mathrm{mg} /$ mouse, cysteine $0.4 \mathrm{mg} /$ mouse, $\mathrm{N}$-acetyl-L-cysteine $0.8 \mathrm{mg} / \mathrm{mouse}$, selenium $0.07 \mathrm{mg} /$ mouse and aspirin $0.6 \mathrm{mg} / \mathrm{mouse}$. All plant extracts were moisture free

All ingredients of plants were extracted by ethyl alcohol $99 \%$ for one week then alcohol was evaporated. Whole plant extracts were dissolved by Propylene 
Glycol then added the water, propylene did not exceed than 5\%.

\subsection{Cancer Cells}

- Ehrlich Ascites Carcinoma (EAC) bearing mice were obtained from the National Cancer Institute, Cairo, Egypt. Ehrlich Ascites Carcinoma cells were maintained in mice through serial intra peritoneal transplantation of $1 \times 10^{6}$ viable tumor cells in $0.2 \mathrm{ml}$ saline.

\subsection{Animals}

- 120 females' healthy Swiss albino mice ( $\pm 18 \mathrm{~g})$ were obtained from the Laboratory Animal House, National Cancer Institute, Cairo, Egypt.

- 120 healthy live African catfish (200 - $250 \mathrm{~g})$ were obtained from the local market, Ismailia, Egypt.

\subsection{In Vivo Study (Experimental Design)}

\section{1) Mice}

120 females Swiss albino mice were maintained for one week acclimation period and were kept on commercial standard diet and tap water until the end of the experiment. Mice were divided into six groups as following.

Group-1 (negative control): 20 mice were injected I.P with saline $0.9 \mathrm{NaCl}$.

Group-2 (treated only): 20 mice were given the experimental formula in drinking water $3 \mathrm{ml} /$ mouse daily.

Group-3 (positive control): 20 mice were injected I.P with Ehrlich Ascites Carcinoma cells $1 \times 10^{6} \mathrm{cell} /$ mouse.

Group-4 (positive treated): 20 mice were injected I.P with Ehrlich Ascites Carcinoma cells $1 \times 10^{6} \mathrm{cell} /$ mouse and were treated orally by the experimental formula ( $3 \mathrm{ml} /$ mouse daily) in drinking water.

Group-5 (positive control): 20 mice were injected sub-cut with Ehrlich Ascites Carcinoma cells $1 \times 10^{6}$ cell $/$ mouse.

Group-6 (positive treated): 20 mice were injected sub-cut with Ehrlich Ascites Carcinoma cells $1 \times 10^{6}$ cell/mouse and were treated by the experimental formula ( $3 \mathrm{ml} /$ mouse daily) orally in drinking water.

2) Fish

120 female and male catfish (Clariasgariepinus) $25 \mathrm{~cm}$ length and $200-250$ g) were maintained for one week acclimation period on commercial standard diet. Fish were housed in fully prepared aquaria and will be divided into six groups as following:

Group-1 (negative control): 20 fish were injected I.P with saline $0.9 \mathrm{NaCl}$.

Group-2 (treated only): 20 fish were given experimental formula ( $10 \times$ mouse dosedaily) in 7.5 grams food/fish daily.

Group-3 (positive control): 20 fish were injected I.P with Ehrlich Ascites Carcinoma cells $1 \times 10^{6} \mathrm{cell} /$ fish.

Group-4 (positive treated): 20 fish were injected I.P with Ehrlich Ascites 
Carcinoma cells $1 \times 10^{6}$ cell/fish and were treated ( $10 \times$ mouse dose daily) in 7.5 grams foods / fish

Group-5 (positive control): 20 fish were injected sub-cut with Ehrlich Ascites Carcinoma cells $1 \times 10^{6}$ cell/fish.

Group-6 (positive treated): 20 fish were injected sub-cut with Ehrlich Ascites Carcinoma cells $1 \times 10^{6}$ cell/mouse and were treated ( $10 \times$ mouse dose daily ) in 7.5 grams food/fish.

All procedures relating to care and maintenance of the animals and fish were in accordance with the international guiding principles for the care and the use of laboratory animals. The experimental design was approved by the Scientific Ethical Committee, Faculty of Veterinary Medicine, Suez Canal University (approval no. 2019029).

\subsection{Sampling}

The samples were collected from all mice groups at the $8^{\text {th }}$ day after inoculation then, weekly.

\subsubsection{Collection of Ehrlich Ascites Carcinoma Fluid}

The ascetic fluid in peritoneal cavity of tumor injected mice was collected by puncture for Measuring the volume of the fluid, Counting the number of tumor cells, detecting apoptotic bodies and immunohistochemical detection of Caspase-3 enzyme in cell blocks; which is a marker of cell death programs.

\subsubsection{Tumor Parameters Evaluation}

- Tumor volume: tumor volume of ascetic fluid from each mouse was measured using a graduated cylinder.

- Tumor cell count: the ascetic fluid was taken in a WBC pipette and diluted to 100 times. Ten microliters of ascetic fluid were diluted with $0.9 \%$ saline up to $1000 \mu \mathrm{L}$ (1:100), mixed well, then a drop of the diluted cell suspension was placed on the Neubauer's counting chamber and the numbers of cells in the 64 small squares will be counted. The cells were stained with trypan blue ( $0.4 \%$ in normal saline) dye. The cells that did not take up the dye were considered viable, and those that took the dye were considered nonviable.

No. of cells per $\mathrm{ml}=$ the average cell count per square $\times$ dilution factor $\times 10^{4}$.

\subsubsection{Collection of Blood Samples}

Three blood samples were collected by puncture of the cardiac mice under light anesthesia.

1) First sample was freshly collected for measuring $\mathrm{pH}$ by $\mathrm{pH}$ meter.

2) The Second sample was collected in EDTA tube for determination the effects of formula on the immune system by counting RBCs and total WBCs according.

To a previous described method [9] differential leukocytes count were carried out from giemsa stained blood smears; as previously described [10], also hemoglobin content was measured; as previously described [11].

3) The third sample was left for clotting and centrifuged at 3000 round/minute 
for 10 minutes for serum separation for biochemical analysis for determination liver function, by measuring the level of aspartate transaminase (AST) and alanine transaminase (ALT) and kidney function, by measuring Urea and Creatinine serum levels.

\section{A) Determination of liver function tests}

Aspartate transaminase (AST) and alanine transaminase (ALT) activities were determined by the colorimetric method using ready-made kits produced by Diamond; as previous described [12].

\section{B) Determination of kidney function tests:}

1) Determination of urea:

Urea was determined in serum samples using ready-made kits produced by Diamond; as previous described [13].

\section{2) Determination of creatinine:}

Creatinine was determined in serum samples using ready-made kits produced by Diamond; as previous described [14].

\subsection{Histopathological Examination}

Specimens of the heart, liver and kidney, spleen and intestine were freshly taken for histopathological examination. They were fixed in 10\% formalin, then washed in running tap water, then dehydrated and cleared in different concentration gradients of alcohol and, with xylene, then embedded in paraffin wax and sliced into thin sections of 5 microns thickness. Sections were stained with H\&E stain then were examined microscopically [15].

\subsubsection{Immunohistochemical (IHC) Study}

Immunohistochemical (IHC) staining was carried out with the streptavidin-biotin method; as previously described by[16]. Primary antibody against casapse 3 (Genemed-biotechnologies, USA, Lot-61125818) was used. This was followed by $60 \mathrm{~min}$ incubations with secondary antibodies (Envision + System-HRP Labelled Polymer, Dako, Glostrup, Denmark) and visualization with the Liquid DAB + Substrate Chromogen System (Dako). All slides are lightly counterstained with hematoxylin for $30 \mathrm{~s}$ prior to dehydration and mounting. All slides were examined by the researcher and another pathologist. Casapse 3 was considered positive when cells displayed cytoplasmic staining. The Percentage of positive cells was recorded.

\subsubsection{Immunohistochemical Scoring}

Immunohistochemistry scoring (Histoscore) was performed using a modified scoring method as previously reported [17] Briefly, total cells and cells with positive staining were counted and the percent positive cells in each high power field was calculated. Fields were then assigned a relative staining intensity score, in three different high power fields $(400 \times)$ for each tumor section: $0=$ negative, 1 = weaks, 2 = moderate, $3=$ strong. The product of the percent positive cells and staining intensity was then derived to create a histoscore of 0 - 300 for each 
high power field: $[1 \times(\%$ cells $1+)+2 \times(\%$ cells $2+)+3 \times(\%$ cells $3+)]$.

\subsection{Statistical Analysis}

Hematological, liver and kidney parameters were examined using one-way ANOVA followed by Fisher's post hoc test to detect significant differences at a probability level of $5 \%(\mathrm{p} \leq 0.05)$. Other data were analyzed using Students " $\mathrm{t}$ " test. All data were expressed as the mean \pm SE.

\section{Results \& Discussion}

One of the important features in the process of carcinogenesis is the ability of cancer cell to flee from death by blocking the intrinsic and extrinsic programs of cell death [6]. The core of this paper is reactivating the death programs in cancer cells by inhibiting the activation of NF-kB, which is responsible for producing the six factors used by cell to shut down the intrinsic and extrinsic pathways of programs of cell death.

The strategy of our study was designed to shut down all transformation stages, by preventing new hydrogen peroxide formation and converting the present into water, and inhibiting kinase enzyme to completely inhibit the NF-kB activation.

\subsection{Strategy of Experimental Formula}

\subsubsection{Removing the Carcinogenic Substances out of Cancer Cells}

The Cell membrane consists of two layers of phospholipid; each layer is composed of lipids and phosphate groups. The Lipid layer is hydrophobic but phosphate groups are hydrophilic. As the phosphate groups are facing to cytoplasm, so the inner surface of the cell membrane is hydrophilic. The movements of the molecules in or out of the cells are controlled by the hydro-property of those molecules [17].

Carcinogenic molecule is hydrophobic, so that it can easily move into cell but so difficult to move out, due to the hydrophilic nature of the inner surface of cell membrane [18].

The hydrophobic molecules expel away from phosphate groups from all directions (the power of dissonance is equal from all directions). So, the hydrophobic molecules are kept away from inner surface of cell membrane and remain in the middle of cells, and thus remain for long time resulting in accumulation. The cell gets rid of these molecules by detoxification enzymes.

Phase-II detoxification enzymes (glutathione-S transferase, UDP Glucuronlytransferases, Sulfotransferases, Methytransferases, Arylamine N-acetyltransferases, and Amino acid conjugating) conjugate certain groups to hydrophobic molecules to increase their solubility, leading to move it from middle of the cell to the cell pole. Each hydrophobic molecule needs certain detoxification enzyme to donate it to a specific group to increase its solubility.

Cancer cell may contain several types of hydrophobic molecules, so in order to move them to the pole of cell, it needs several types of detoxification enzymes. 
Thus we must activate all phase-II detoxification enzymes to move all types of carcinogenic molecules from the middle of cell to peripheral of the cell near the phosphate groups of the inner surface of the cell membrane, to prepare them for plumbing out of cell. The productions of phase-II detoxification enzymes are controlled by a protein called nuclear factor erythroid-derived 2 (Nr-F2) [19] [20]. Sulforaphane which presents in Broccoli improves the expression of the Nr-F2, which stimulates the production of the phase-II detoxification enzymes [21].

Phase-III detoxification enzymes are necessary to excrete the newly formed phase-II products out of the cell. They belong to a family of proteins called the ATP-binding cassette $(\mathrm{ABC})$ transporters [22]. The molecules require chemical energy, in the form ATP, to actively pump the carcinogenic molecules through the cell membrane and out of the cell [23].

Polyphenols which present in Apples stimulate phase-III detoxification enzymes which pump the carcinogenic molecules out of the cell [24].

\subsubsection{Regulating the Detoxification Phase-I Enzymes}

Phase-I enzymes begin the detoxification process by chemically transforming lipid soluble compounds to water soluble compounds in preparation for phase-II. The accumulation of harmful substances leads to high levels of phase-I detoxification enzymes to metabolize them. Each molecule of the harmful substances needs one molecule of phase-I detoxification enzyme to metabolize it. The result of this process is the generation of one molecule of free radical [25]. Chemical analysis of cancer cells showed elevated levels of phase-I detoxification enzymes, as Cytochrome P450 (CYP) 1B1. It performs the bulk of phase-I reaction and serves as a source of superoxide anion and hydrogen peroxide [26] [27]. Grapefruit contains naringenin (the principal flavonoid in grape fruit), hesperetin and eriodictyol which reduce the cytochrome P450, where it represents the bulk of oxidation processing [28].

Xanthine dehydrogenase/Xanthine oxidase which is the major cytoplasmic source of superoxide radicals and hydrogen peroxide is also present in a high level in tumor cells compared to normal cell [29] [30]. Red grape \& cherries, containing high flavonoid (anthocyanidins and cyanidin). Also, black grapes and blackberries are high in flavonoids epicatechin and catechin, all inhibit Xanthine enzyme and amino mono-oxidase enzymes [31].

In addition, the metabolism of polyamines by monoamine oxidase enzymes (MAO-A \& MAO-B) which are found on the outer membrane of cells mitochondria-generates locally high concentrations of hydrogen peroxide [32] [33] [34]. Turmeric contains the curcumin which has a potent activating E-cadherin expression and prevents the activity of the nuclear factor Kappa $B$ and inhibits both MAO-A and MAO-B and increases the level of Serotonin and Dopamine [35]. Morefore, Cur cumin possesses activity against cancer by activating apoptotic pathways in cancer cell and inhibiting pro-cancer processes including inflammation [36].

As a significant side effect of the phase-I detoxification process is production 
of free radicals and hydrogen peroxide, for each molecule of toxin or carcinogenic substances metabolize by phase-I detoxification enzymes, one free radical molecule is generated. So, phase-I detoxification enzymes are the major source of free radicals generation [25].

\subsubsection{Scavenging Free Radicals Especially Oxygenate Origin}

The free radicals are molecules, ions or atoms with unpaired electrons in their outer shell of electrons. They are highly reactive due to the presence of unpaired electron(s). Free radicals formation occur continuously in the cells as a consequence of both enzymatic and non-enzymatic processes [37]. Accumulation of harmful substances in cell results in activating the detoxification phase I enzymes, resulting in excessive generation of free radicals as superoxide anion and hydrogen peroxide. Ionizing radiation also in the presence of $\mathrm{O}_{2}$, converts superoxide, hydroxyl radical and organic radicals to hydrogen peroxide [38].

Free radicals are controlled by the antioxidant system, both enzymatic and non-enzymatic; the latter couldn't be formed by the body and are obtained from foods, such as vitamin C, A and E [39].

Vitamin-C (ascorbic acid) inhibits protease enzyme allowing collagen fibrils to be restored and accumulate in extracellular space within 11 days [40]. This leads to the proper positioning of death receptor to adhere to ligand, this facilitates the working the extrinsic program of cell death.

Beta carotene inhibits the oxidant-induced NF-kB activation and the production of interleukin IK-6 and tumor necrotic factor alpha [41] [42].

Vitamin-E reduces the accumulation of superoxide radical and decreases the generation of oxidative damage substances [43].

Enzymatic anti-oxidants include, sodium dimustase enzyme which converts superoxide anions to hydrogen peroxide and Catalase and Glutathione enzymes which convert hydrogen peroxide (activator of NF-kB) to water and oxygen and improve apoptosis [44] [45].

Other compounds that have antioxidant activity such as flavonoids and $\mathrm{N}$-Acetyl-L-cysteine which increases the intracellular level of glutathione [46]. They act by donating the acetyl group to oxidized glutathione so that, it can be reduced form and works effectively. So, $\mathrm{N}$-acetyl-L-cysteine serves as a co-substance to eliminate hydrogen peroxide and inhibit the activation of NF-kB [47] [48].

\subsubsection{Keeping the NF-kB in Inactive Form}

NF-kB is kept in inactive form by controlling both hydrogen peroxide and kinase enzyme. The excessive amount of hydrogen peroxide are produced directly by phase-I detoxification enzymes and indirectly, by sodium dimustase enzyme which converts the superoxide free radical to hydrogen peroxide.

In non-stimulated cells, both NF-kB and dynein light chain (LC8) bind with inhibitor kappa B (IKB- $\alpha$ ) in the cytosol of the cell forming (NF-kB,-IKB- $\alpha$, -LC8) complex.

LC8 inhibits the activation of NF-kB by interacting with IKB- $\alpha$ and thereby, 
preventing its phosphorylation by kinase enzyme. When cells are exposed to $\mathrm{H}_{2} \mathrm{O}_{2}$, the LC8 forms a reversible intermolecular disulfide bond between the two $\mathrm{CYs}^{2}$ residues, leading to a conformational change that results in dissociation of LC8 from this complex while IKB- $\alpha$ and NF-kB remain bound together [49]. This dissociation of LC8 from (NF-kB, IKB- $\alpha$ and LC8) complex allows kinase enzyme (IKKs) to phosphorylate the inhibitor kappa B (IKB- $\alpha$ ).This phosphorylation results in dissociation of IKB- $\alpha$ from NF-kB. Finally, NF-kB becomes free and trans locates into the nucleus and stimulates the expression of several genes including the genes that play a direct role in the shutdown of the intrinsic and extrinsic programs of cell death as( Muc-1, Bcl-2, MMPs and Decoy-R3) and indirect role as TNF- $\alpha$ gene which stimulates the expression of (Muc-1, Muc-4 and Muc-16) [8]. Moreover, NF-kB responsible for the production of several cytokines which activate IKB kinase (IKKs), which phosphorylates IKB- $\alpha$ leading to the reactivation of NF-kB. Thus, establishing a positive auto regulation loop that can amplify the inflammatory response and increase the duration of inflammation [50] (Figure 1).

Therefore, $\mathrm{H}_{2} \mathrm{O}_{2}$ is the first step for activation of NF-kB and that the NF-kB needs in addition IKKs to be active. The activated NF-kB is responsible for the cell fleeing from death and its conversion to cancer cell [8].

Glutathione is the most important antioxidant for neutralization the free radicals which donates electron to $\mathrm{H}_{2} \mathrm{O}_{2}$ reduce it into $\mathrm{H}_{2} \mathrm{O}+\mathrm{O}_{2}$ [46].

The ratio of the main active form of glutathione (the reduced glutathione) to depleted glutathione (Oxidized glutathione) within a cell is often used as a measure of cellular toxicity and carcinogens. Glutathione S-transferase (GST)

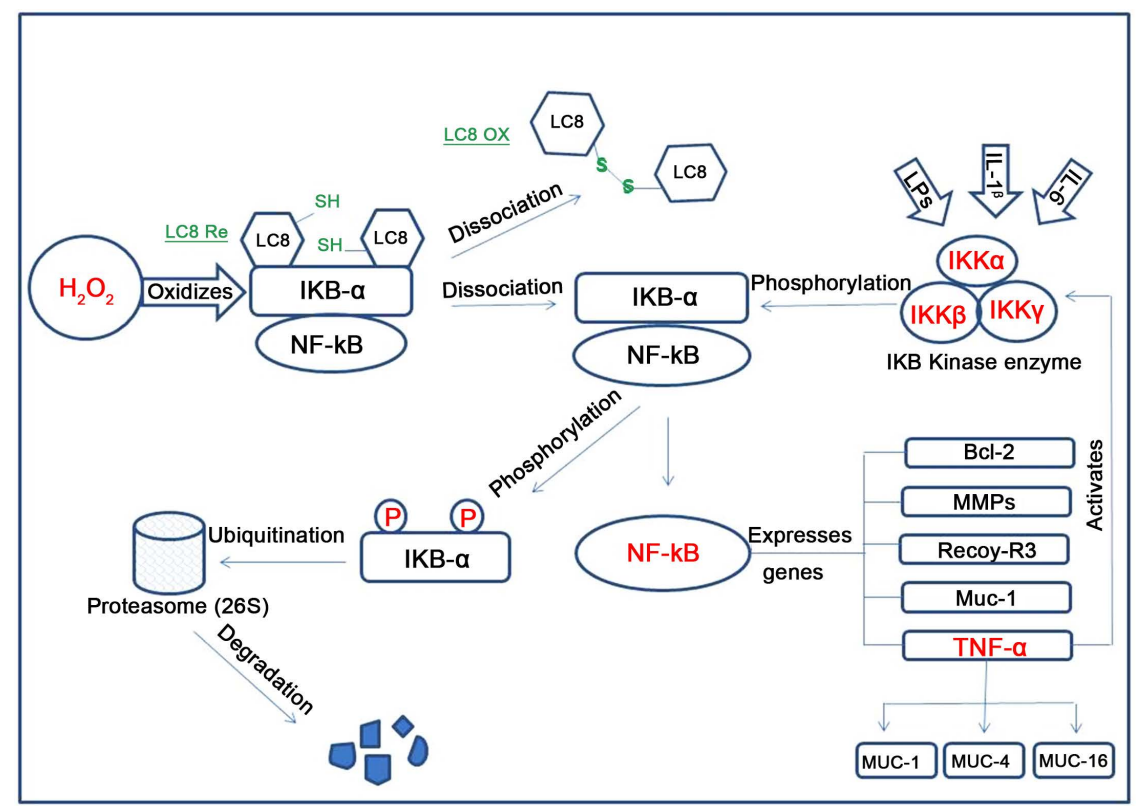

Figure 1. shows $\mathrm{H}_{2} \mathrm{O}_{2}$ oxidizes the LC8 leading in dissociate it from IKB- $\alpha$, then IKKs phosphorylate the IKB- $\alpha$, resulting in free NF-kB, which Trans locates into nucleus and stimulates the expression of genes which responsible for shutdown the pathway of the intrinsic and extrinsic programs of cell death. TNF- $\alpha$ reactive the NF-kB by stimulates lkks [8]. 
are family of enzymes that recycle oxidized glutathione. Conjugation of reduced glutathione to a wide range of substrates and their activity depends on adequate dietary sulfur-containing amino acids (methionine or cysteine), vitamin B6 for the conversion of methionine to cysteine, as well vitamins B2 and B3. Cysteine is the critical amino acid needed for synthesis of glutathione (GSH) [47].

Selenium is an essential trace element and co-factor for glutathione peroxidase.

Cur cumin improves the active form of glutathione (i.e., reduced glutathione), [46].

$\mathrm{N}$-acetyl-L-cysteine increases the intracellular level of GSH by donating the acetyl group to oxidized glutathione, so that it can be transformed back to its reduced form and work effectively. So, N-acetyl-L-cysteine serves as a co-substance to elimination $\mathrm{H}_{2} \mathrm{O}_{2}$ and inhibits the activation of NF-kB [48].

Moreover, the anti-inflammatory effects of Aspirin and sodium salicylate results from their specific inhibition of ATP-binding to IKK $\beta$ and Thus, reducing IKK $\beta$-dependent phosphorylation of IkB- $\alpha$, preventing the activity of NF-kB pathway [51].

\subsection{Sensitivity of Ehrlich Ascites Carcinoma Cells (EAC)}

Cells were inoculated (I.P and sub-cut) into mice and fish. The results showed that there was no growth of EAC among the African cat fish. On the other hand, there was rapid growth of EAC among the mice which were inoculated (I.P and sub-cut).

\subsection{Parameters of Death Programs Activity}

\subsubsection{The Volume of Ascites Fluid}

At $8^{\text {th }}$ day of inoculation the Ascites fluid volume of the controlled group of mice which were inoculation I.P with EAC cells was $1.63 \pm 0.176 \mathrm{ml}$ and continued increasing daily until reach to $5.87 \pm 0.384 \mathrm{ml}$ then all mice of this group dead at $21^{\text {th }}$ day after inoculation. On the other side, the ascites fluid volume of treated I.P inoculation group was $1.6 \pm 0.153 \mathrm{ml}$ and continued decreasing gradually until reached zero $\mathrm{ml}$ at the $34^{\text {th }}$ day of I.P inoculation of EAC (Table 1). This means

Table 1. Shows the effect of experimental formula on the ascetic fluid volume $(\mathrm{mL})$ of the intraperitoneal implanted EAC $(n=3)$.

\begin{tabular}{ccc}
\hline \multirow{2}{*}{ The collection day } & \multicolumn{2}{c}{ Ascetic fluid volume $(\mathrm{mL})$} \\
\cline { 2 - 3 } & Positive control & Treated group \\
\hline $8^{\text {th }}$ & $1.63 \pm 0.176$ & $1.60 \pm 0.153$ \\
$14^{\text {th }}$ & $4.67 \pm 0.393$ & $1.37 \pm 0.175^{\star *}$ \\
$18^{\text {th }}$ & $5.87 \pm 0.384$ & $1.03 \pm 0.186^{\star *}$ \\
$21^{\text {st }}$ & All dead & $0.67 \pm 0.120$ \\
$24^{\text {th }}$ & - & $0.43 \pm 0.088$ \\
$34^{\text {th }}$ & - & UD \\
\hline
\end{tabular}

Student's t-test was applied, where ${ }^{\star}=$ significantly different from control at $\mathrm{p} \leq 0.05$ and ${ }^{\star *}=$ significantly different from control at $\mathrm{p} \leq 0.01$. UD $=$ undetected. 
that the experimental formula succeeded to remove the blockers of death programs pathways of cancer cells and return the death programs to work again at $8^{\text {th }}$ day of I.P inoculation of Ehrlich cells carcinoma and continued its work until disappearing cancer cells completely.

\subsubsection{The Size of Solid Cancer}

It was measured at $18^{\text {th }}$ day in positive control sub-cut (EAC) cells inoculation group and treated sub-cut inoculated group. The result revealed the size of the solid cancer was $0.251 \pm 0.033 \mathrm{~cm}^{3}$ in positive control group, and gradually increases until reached to $2.630 \pm 0.221 \mathrm{~cm}^{3}$ at $34^{\text {th }}$ day of sub cut EAC inoculation. While the size of solid cancer in treated group was $0.127 \pm 0.017 \mathrm{~cm}^{3}$ at $18^{\text {th }}$ day of inoculation and gradually decrease until reached to zero at $34^{\text {th }}$ day of sub-cut EAC cells inoculation (Table 2). This means that the death programs of cancer cells return to work again.

\subsubsection{Counting the Number of Cancer Cells}

The result revealed increasing the EAC cell number in the I.P inoculation mice group. The total number of cells in the positive control group was $217 \pm 2.91$ million $/ \mathrm{mL}$, the number of live cells was $197.33 \pm 2.91 \mathrm{million} / \mathrm{mL}$ and the number of death cells was $20.33 \pm 0.67 \mathrm{million} / \mathrm{mL}$, while the total number of cells in treated group was $125.33 \pm 4.67$ million cells $/ \mathrm{mL}$, (the number of live cells was $83.67 \pm 4.26$ million cells $/ \mathrm{mL}$ and the number of death cells was (41.63 \pm 0.88 ). The death cells in treatment group represent $33.21 \%$ from all cells, (Table 3).

Table 2. Shows the effect of the experimental formula on the size $\left(\mathrm{cm}^{3}\right)$ of the subcutaneously implanted solid Ehrlich carcinoma $(\mathrm{n}=3)$.

\begin{tabular}{ccc}
\hline \multirow{2}{*}{ The collection day } & \multicolumn{2}{c}{ Solid Ehrlich carcinoma size $\left(\mathrm{cm}^{3}\right)$} \\
\cline { 2 - 3 } & Positive control & Treated group \\
\hline $28^{\text {th }}$ & $0.251 \pm 0.033$ & $0.127 \pm 0.017^{\star}$ \\
$27^{\text {th }}$ & $0.874 \pm 0.051$ & $0.007 \pm 0.001^{\star *}$ \\
$34^{\text {th }}$ & $2.630 \pm 0.221$ & UD \\
\hline
\end{tabular}

Student's t-test was applied, where ${ }^{*}=$ significantly different from control at $\mathrm{p} \leq 0.05$ and ${ }^{* *}=$ significantly different from control at $\mathrm{p} \leq 0.01$. UD $=$ undetected.

Table 3. Shows suppressive effect of the experimental formula on the intraperitoneally implanted Ehrlich as cites carcinoma cell counts and viability at $18^{\text {th }}$ days post inoculation $(\mathrm{n}=3)$.

\begin{tabular}{cccc}
\hline \multirow{2}{*}{ Groups } & \multicolumn{3}{c}{ Carcinoma cell count $\left(\mathrm{n} \times 10^{6}\right)$} \\
\cline { 2 - 4 } & Total cells $/ \mathrm{mL}$ & Live cells $/ \mathrm{mL}$ & Dead cells $/ \mathrm{mL}$ \\
\hline Positive control group & $217.67 \pm 2.91$ & $197.33 \pm 2.91$ & $20.33 \pm 0.67$ \\
Treated group & $125.33 \pm 4.67^{* *}$ & $83.67 \pm 4.26^{* *}$ & $41.63 \pm 0.88^{* *}$ \\
\hline
\end{tabular}

Student's t-test was applied, where ${ }^{*}=$ significantly different from control at $\mathrm{p} \leq 0.05$ and ${ }^{* *}=$ significantly different from control at $\mathrm{p} \leq 0.01$. UD $=$ undetected. 


\section{Effect of the experimental formula on the cancer cells number}

Death cells number $\div$ Total ascites cells (Death cells + live cells) $\times 100$

$41.63 / 125.33=33.2 \%$.

\subsection{Immunohistochemical Results}

Sections examined from tumor samples showed positive reaction for caspase enzyme in tumor cells, starting from the base of tumor tissue, at the junction with the healthy tissue; it looks like an explosion of several water springs. This proves that the experimental formula succeeded in stimulating the death programs of cancer cells (Figure 2). Positive reaction to caspase enzyme in tumor tissue showed an extension of the reaction deep into cancerous tissue (Figures 3-5). Moreover, we observed the reduced density of the tumor cells near the areas of positive reaction to caspase enzyme, indicating the success of activation of the apoptotic program in eliminating tumor cells (Figure 5). Caspase 3 positivity was observed as moderate immunoreaction in about $15 \%$ of cells of the tumor. So a histoscore of $30 \%$ of the positivity of tumor cells is calculated.

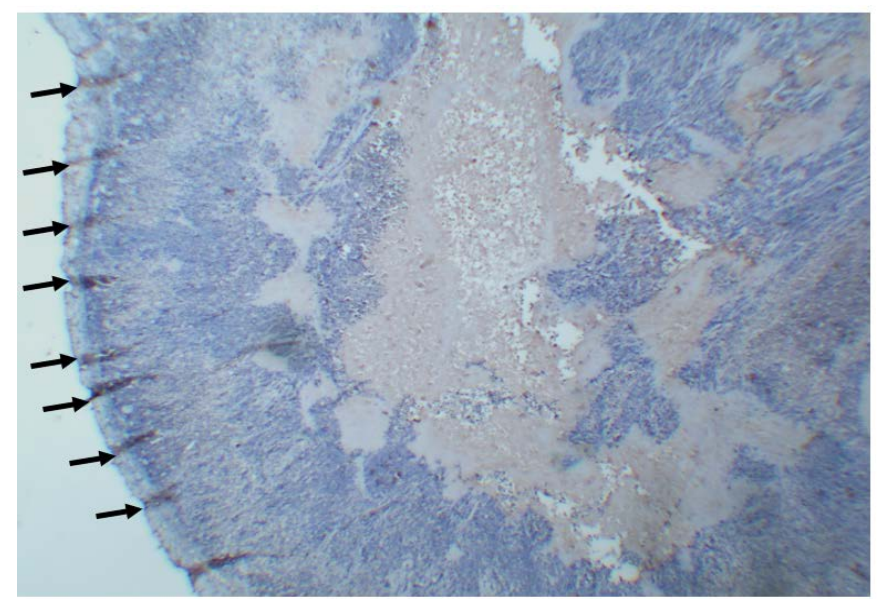

Figure 2. (IHC, $\times 4$ ): A Positive reaction (black arrows) in tumor cells, beginning from base of the tumor, representing about $30 \%$ from the tissue.

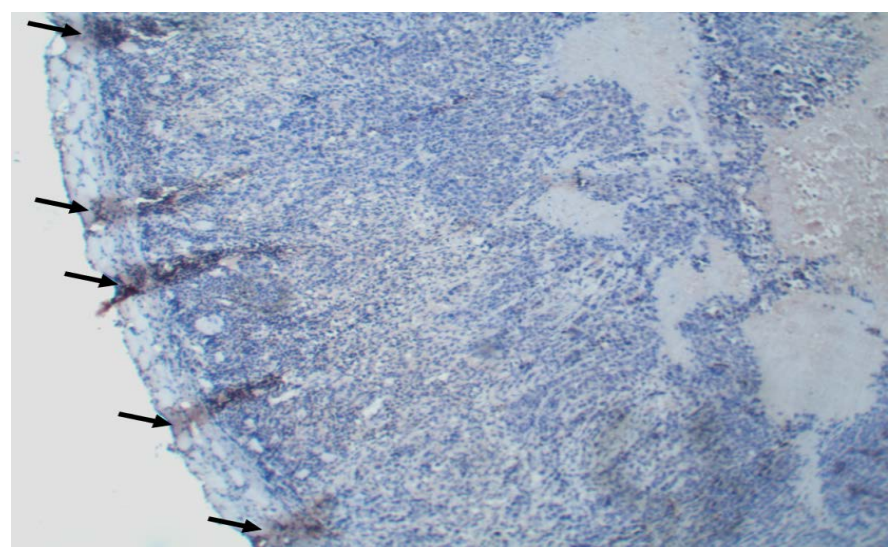

Figure 3. (IHC, $\times 10$ ): A Positive reaction in tumor cells, beginning from the base of the tumor, representing about $30 \%$ from the issue. 


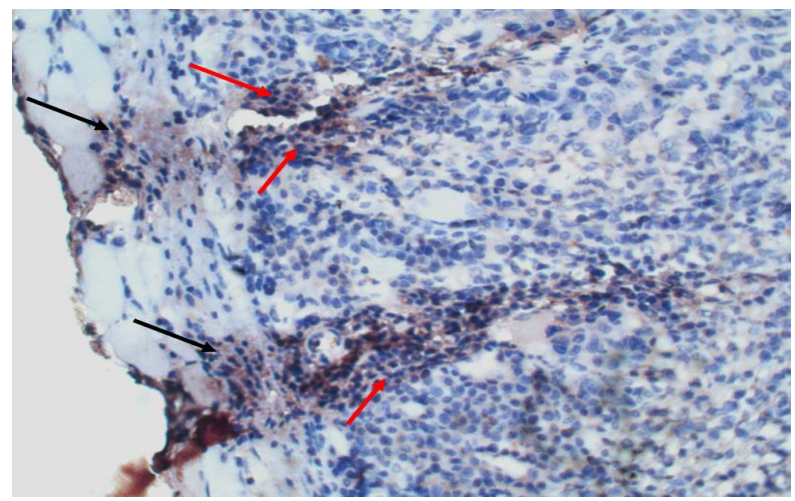

Figure 4. (IHC, $\times 40$ ): Higher magnification of the previous figure showing positive cytoplasmic reaction, starting in base of tumor tissue, at its junction with normal tissue (black arrows) and extending into tumor cells (red arrows).

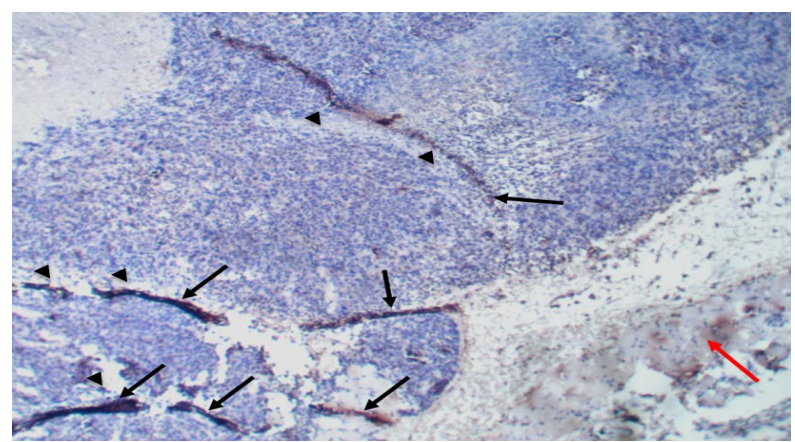

Figure 5. (IHC, $\times 10$ ): Multiple areas in tumor show such positive reaction to caspase enzyme, beginning from tumor base at the junction with muscle (red arrow), and extending deep into tumor cells (black arrows). Such reactivity to caspase enzyme is seen within about $30 \%$ of the tumor tissue. In addition, there is a reduced density of the tumor cells near the areas of positive reaction to caspase enzyme (arrowheads).

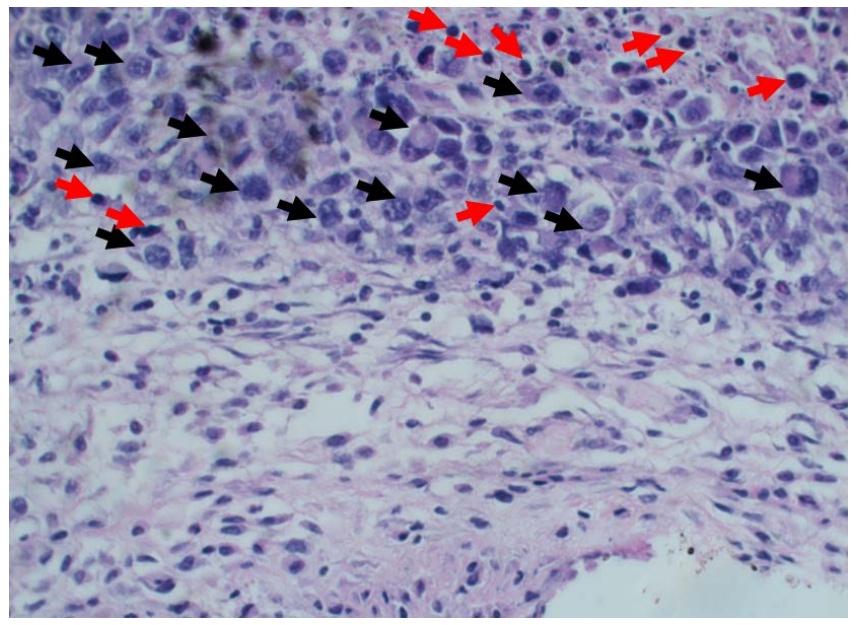

Figure 6. ( $\mathrm{H} \& \mathrm{E}, \times 40)$ : There are numerous macrophages (black arrows) and apoptotic bodies (red arrows) at the base of the tumor.

In addition, histopathological examination revealed numerous macrophages and apoptotic bodies (red arrows) at the base of the tumor, indicating the suc- 
cessful elimination of tumor cells (Figure 6).

The above observation of a decrease in volume of ascetic fluid, reduction in the size of tumor and the detection of caspase enzyme activity; as well as infiltration of tumor tissue by macrophages and presence of apoptotic bodies, all of these indicate the activity of death programs and prove that the death cell programs in cancer cells reworked again.

\subsection{The Effects of the Experimental Formula}

\subsubsection{Hematological Study}

Hematological studies revealed that the experimental formula regulated blood $\mathrm{pH}$ of cancer mice, increasing $\mathrm{RBC}$ count and $\mathrm{Hb}$ concentration. This means that the experimental formula has hematological improvement (Table 4).

The blood $\mathrm{pH}$ values revealed significant $(\mathrm{P}<0.05)$ reduction in non-treated I.P inoculated group than negative control and other treated groups. Hemoglobin values were significantly reduced in non-treated I.P an S.C inoculated groups than the negative control and other groups. These results suggested the presence of anemia due to cancer inoculation [52]. The possible cause of such type of anemia is functional iron deficiency due to cancer progression [53]. Functional iron deficiency means a defect in iron handling instead of a lack of iron, where the total iron-binding capacity was reduced with increased iron storage [54]. The treatment of cancer inoculated mice with apple, blackberries, broccoli, grapefruit, and vitamin-C efficiently ameliorated cancer-induced anemia this could be attributed to [55] [56] [57] [58].

The total leukocytes count was significantly reduced in non-treated I.P an S.C inoculated groups when compared to the negative control. This decline in WBCs count could be illustrated by the progression of cancer that attracted leukocytes by the produced cytokines [59] thus reducing WBCs count in the circulation. These were confirmed by the presence of abundant leukocytes especially macrophages and lymphocytes around and within cancer cells, as observed in (figure [12]). Treated S.C and I.P inoculated mice revealed significant $(\mathrm{P}<0.05)$

Table 4. Shows the suppressive effect of the experimental formula on some hematological parameters at the $8^{\text {th }}$ day post inoculation $(n=5)$.

\begin{tabular}{cccccc}
\hline Mice groups & $\mathrm{pH}$ & $\begin{array}{c}\mathrm{Hb} \\
\mathrm{g} / \mathrm{dL}\end{array}$ & $\begin{array}{c}\mathrm{RBCs} \\
\times 10^{6} / \mu \mathrm{l}\end{array}$ & $\begin{array}{c}\text { WBCs } \\
\times 10^{3} / \mu \mathrm{l}\end{array}$ & $\begin{array}{c}\text { Platelet } \\
\times 10^{3} / \mu \mathrm{l}\end{array}$ \\
\hline Negative control & $7.36 \pm 0.05^{\mathrm{a}}$ & $10.18 \pm 0.63^{\mathrm{ab}}$ & $7.14 \pm 0.48^{\mathrm{b}}$ & $11.18 \pm 0.54^{\mathrm{a}}$ & $321.6 \pm 21.17^{\mathrm{c}}$ \\
Treated non-inoculated & $7.32 \pm 0.05^{\mathrm{a}}$ & $11.04 \pm 0.68^{\mathrm{a}}$ & $8.88 \pm 0.58^{\mathrm{a}}$ & $9.08 \pm 0.77^{\mathrm{b}}$ & $310.0 \pm 22.08^{\mathrm{c}}$ \\
Non-treated I.P inoculated & $7.20 \pm 0.04^{\mathrm{b}}$ & $9.14 \pm 0.55^{\mathrm{b}}$ & $4.82 \pm 0.51^{\mathrm{c}}$ & $7.32 \pm 0.72^{\mathrm{cd}}$ & $489.4 \pm 28.64^{\mathrm{a}}$ \\
Treated I.P inoculated & $7.30 \pm 0.03^{\mathrm{a}}$ & $10.90 \pm 0.58^{\mathrm{a}}$ & $8.04 \pm 0.66^{\mathrm{ab}}$ & $6.54 \pm 0.63^{\mathrm{d}}$ & $387.2 \pm 30.70^{\mathrm{b}}$ \\
Non-treated S.C inoculated & $7.35 \pm 0.04^{\mathrm{a}}$ & $9.12 \pm 0.51^{\mathrm{b}}$ & $5.22 \pm 0.55^{\mathrm{c}}$ & $8.32 \pm 0.61 \mathrm{~b}^{\mathrm{c}}$ & $518.8 \pm 30.93^{\mathrm{a}}$ \\
Treated S.C inoculated & $7.34 \pm 0.04^{\mathrm{a}}$ & $10.84 \pm 0.57^{\mathrm{a}}$ & $7.44 \pm 0.57^{\mathrm{b}}$ & $6.46 \pm 0.56^{\mathrm{d}}$ & $390.8 \pm 27.71^{\mathrm{b}}$ \\
\hline
\end{tabular}

Data are expressed as means $\pm S E M, n=5$. Values having different alphabetic superscripts within the same column are significantly different at $\mathrm{p} \leq 0.05$. 
reduction in WBCs count than cancer inoculated non treated group. This demonstrates the ability of glutathione in reducing cancer cells induced cytokines that capable of reducing WBCs chemotactic response to cancer area [60].

On the other side, the platelets count was significantly $(\mathrm{P}<0.05)$ increased in S.C and I.P inoculated groups. The treatment of cancer inoculated groups with glutathione significantly $(\mathrm{P}<0.05)$ reduced this elevation in platelet counts than inoculated non treated mice [60]. Present results are logic where previous literature confirmed the close association between cancer progression and platelets activation that was pivotal for cancer progression and activation [61] [62].

\subsubsection{Biochemical Studies}

Biochemical studies showed activation of the liver enzyme AST and mild activation of ALT enzyme. But the parameters of kidney were nearly at normal level see (Table 5).

The results revealed that the levels of Liver enzymes (AST and ALT) were significantly different; the level of these enzymes in the treated non-inoculation group was higher than control negative group. Also, non-treated I.P inoculated group was elevated while the level of these enzymes was decreased after treated by experimental formula but still higher than control and treated only group. But the highest levels of these enzymes were presence in sub-cut inoculation group.

The function of liver enzymes AST \& ALT is responsible for transferring the amino group (NH2) between an amino acid and an $\alpha$-ketoacid. They are important in the synthesis of amino acids, which form proteins [63]. The level of liver enzymes (AST \& ALT) is higher in children than adults, also $25 \%$ higher than adult in strenuous exercise man [64] [65]. This means that the level of these enzymes elevate during building new cells as well as break down of cells. So we can explain the elevating of the level of enzymes in treated non-inoculated group is due to building immune cells especially lymphocytes and in non-treated inoculation I.P group due to build more cancer cells. Then the level of these enzymes decreases due to stop the cell division program and returning the death program of cancer cell to work. While the highest level in sub-cut inoculated group due to building blood vessel in tumor tissue in addition, building new Cancer cells.

Table 5. Shows the influence of experimental formula on some liver and kidney biomarkers in normal and in Ehrlich Ascites carcinoma-bearing mice.

\begin{tabular}{ccccc}
\hline Mice groups & AST $(\mu / \mathrm{ml})$ & ALT $(\mu / \mathrm{mL})$ & Urea $(\mathrm{mg} / \mathrm{dL})$ & Creatinine $(\mathrm{mg} / \mathrm{dL})$ \\
\hline Negative control & $142.2 \pm 6.82^{\mathrm{e}}$ & $64.8 \pm 4.66^{\mathrm{b}}$ & $36.1 \pm 3.21^{\mathrm{ab}}$ & $0.60 \pm 0.07^{\mathrm{b}}$ \\
Treated non-inoculated & $225.2 \pm 11.57^{\mathrm{d}}$ & $79.7 \pm 7.66^{\mathrm{b}}$ & $37.3 \pm 3.12^{\mathrm{ab}}$ & $0.72 \pm 0.10^{\mathrm{ab}}$ \\
Non-treated I.P inoculated & $272.6 \pm 15.21^{\mathrm{c}}$ & $87.8 \pm 9.01^{\mathrm{b}}$ & $34.6 \pm 3.44^{\mathrm{ab}}$ & $0.62 \pm 0.09^{\mathrm{ab}}$ \\
Treated I.P inoculated & $244.1 \pm 15.49^{\mathrm{cd}}$ & $77.7 \pm 8.11^{\mathrm{b}}$ & $41.2 \pm 5.25^{\mathrm{a}}$ & $0.82 \pm 0.11^{\mathrm{ab}}$ \\
Non-treated S.C inoculated & $958.4 \pm 25.66^{\mathrm{a}}$ & $260.2 \pm 17.50^{\mathrm{a}}$ & $32.1 \pm 3.36^{\mathrm{b}}$ & $0.76 \pm 0.12^{\mathrm{ab}}$ \\
Treated S.C inoculated & $770.0 \pm 22.78^{\mathrm{b}}$ & $249.2 \pm 9.48^{\mathrm{a}}$ & $40.3 \pm 4.13^{\mathrm{ab}}$ & $0.84 \pm 0.13^{\mathrm{a}}$ \\
\hline
\end{tabular}

Data are expressed as means $\pm S E M, n=5$. Values having different alphabetic superscripts within the same column are significantly different at $\mathrm{p} \leq 0.05$. 
On other sides the measuring of kidney function by measuring the level of urea and creatinine. The elevating levels means the deamination process of amino acids was increased as a product of cell break down, as evidence of the death program activity. The levels of urea and creatinine were elevated but nearly at normal level see (Table 5).

\subsubsection{Histopathological Study}

Histopathological examination of the control group revealed no significant pathological changes. In treated only group, examination of liver and renal tissue revealed normal tissue architecture, with minimal degenerative changes in hepatocytes and tubular epithelium of kidney. Examination of spleen and intestinal tissue revealed lymphocytic proliferation with hyperplastic lymphoid follicle in spleen and laminapropria and submucosa of intestine (Figures 7-9).

In the cancer group which received no treatment, there was the marked proliferation of cancer cells at the site of inoculation extending deeply between muscle bundles (Figure 10(a) and Figure 10(b)). Examination of the internal organs revealed an increase in degenerative changes in the hepatocyte (Figure $11)$.

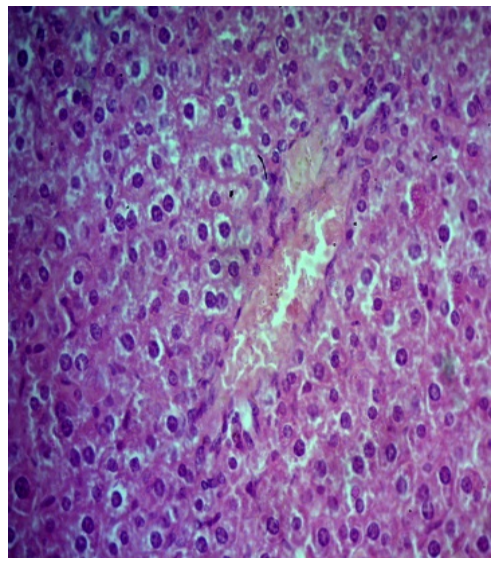

Figure 7. (H \& E, $\times 10)$ : Mild hydropic degenerative changes in hepatocytes of the liver.

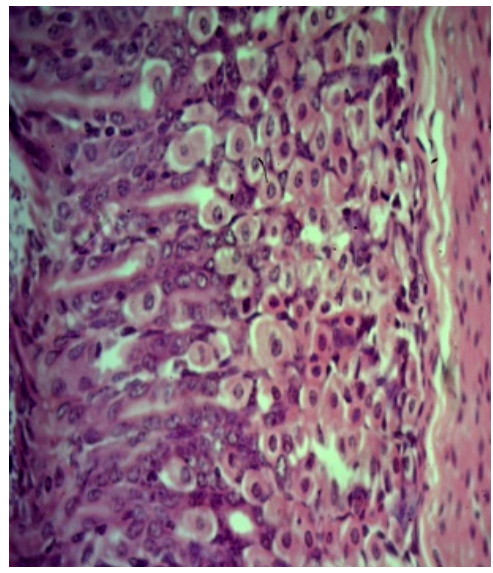

Figure 8. (H \& E, $\times 40)$ : A proliferation of lymphocytes in lamina propria of intestine. 


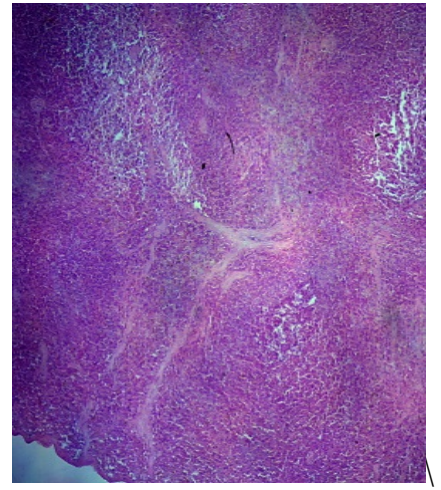

Figure 9. (H \& E, $\times 10)$ : hyperplastic lymphoid follicles of spleen.

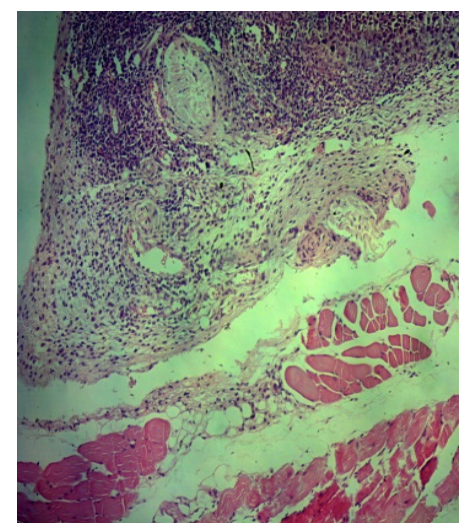

(a)

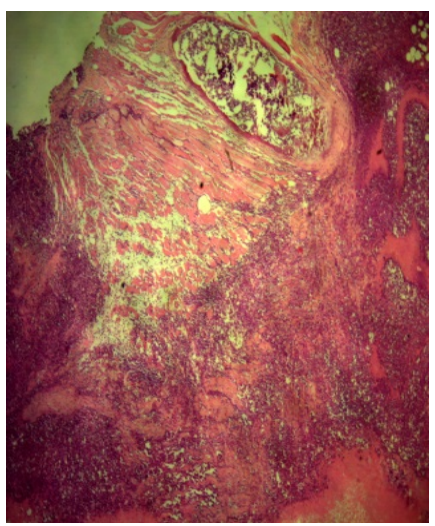

(b)

Figure 10. ( $\mathrm{H} \& \mathrm{E}, \times 10)$ : The tumor site injection showing proliferation of the cancer cells.

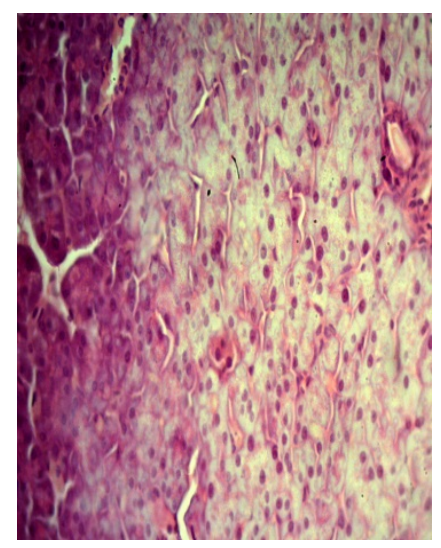

Figure 11. (H \& E, $\times 40)$ : degenerative changes in the hepatocytes.

In the cancer group which received treatment, there were numerous macrophages and apoptotic bodies at the base of the tumor, with its junction with normal tissue, indicating successful elimination of tumor cells (Figure 6 and Figure 12). In addition, there was marked lymphocytic infiltration within tumor tissue. Liver cells exhibited congested sinusoids with hydropic degeneration of hepatocytes, while kidney cells show mild acute tubular injury. 


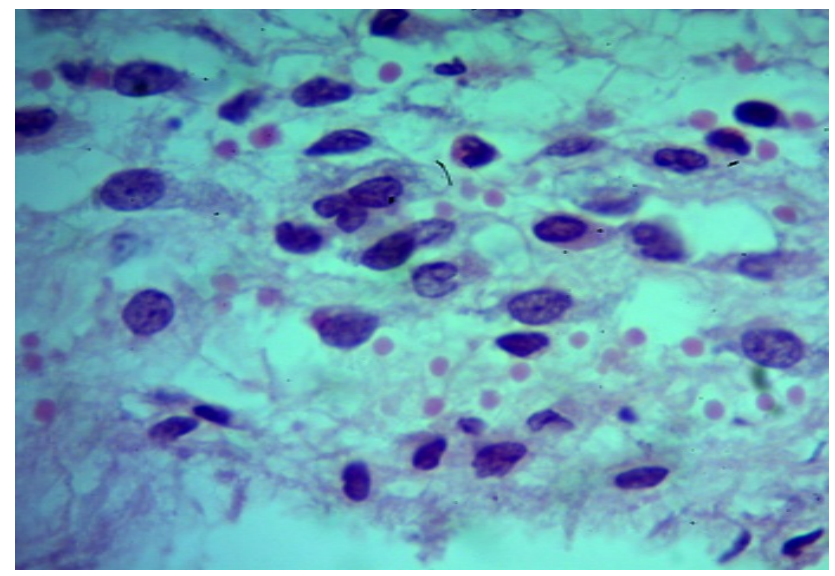

Figure 12. Tumor site showing macrophages and apoptotic bodies at the junction between tumor and healthy muscles.

\subsubsection{Experimental Formula}

Experimental formula succeeded in bringing the death program of cancer cells back to work again strongly leading to decrease in cancer tissue mass within 34 days. This was proved by immunohistochemical detection of caspase- 3 enzymes, indicating the activation of apoptotic pathways in cancer cells. In addition, the histopathological study revealed that there no significant pathological changes in the internal organs, confirming the specificity of designed formula.

In accordance with that the hematological study revealed that the experimental formula improves the patient healthy by increasing $\mathrm{RBC}$ count and $\mathrm{Hb}$ concentration and restoring the $\mathrm{pH}$ of blood to normal. Moreover, the biochemical study revealed no toxic effect was observed during the use of formula.

The experimental formula contains natural plants, vitamins, glutathione, and aspirin. So, it could be given orally in a diet program or in a suspension form or in the form of capsules.

The experimental formula should be subjected to further intense research to determine the lowest effective dose, measuring LD50, as well as raising white blood cells also to modify it.

\section{Conclusion}

The positive reaction of caspase enzyme proved that the experimental formula succeeded in "switching on" back the death program of cancer cells and showed that such cells death stated at the base of cancer tissue. The formula was effective and led to a significant reduction in tumor mass within 34 days. It exerts its effect on cancer cells only, making it safe and with no observed side effect.

\section{Acknowledgements}

Firstly, I wish to express sincere gratitude and deepest thanks to "ALLAH" who guided me, pushed me, supported me and gave me everything, and his divine favors, countless.

Secondary, I would like to express deepest thanks to Prof. Ass. Heba Abd Era- 
zek, Physiology Department, Suez Canal University and all colleagues and workers in the laboratory, Suez Canal University, who facilitate my work.

I would also like to thank Shaimaa Mostafa Mohamed, a young veterinarian, who has helped me in the wording of this paper.

Finally, I would like to thank Rasha Mohamed Mostafa, Computer Specialist, for great assistance to me in presenting this paper in its computerized form.

Praise is to Allah who guided us to his path of righteousness and without whose guidance we would have missed it. Indeed, his messengers have brought us the truth.

\section{Conflicts of Interest}

The authors declare no conflicts of interest regarding the publication of this paper.

\section{References}

[1] Wikipedia (2019) Atomic Bombings of Hiroshima and Nagasaki. http://en.wikipedia.org/wiki/atomicbombingsofhiroshimaandnagasaki

[2] WHO (2015) http://www.who.int/cancer/en

[3] WHO (2017) WHO/World Cancer Day 2017-World-Health Organization. WHO, Geneva.

[4] WHO/Cancer (2015) http://www.who.int/cancer/en

[5] National Cancer Institute. http://www.cancergov/about-cancer/treatmenttypes

[6] Elkhodary, M.S.M. (2018) Quranic Verse No. 8 of Surat Al-Jumu'ah Describes Cancer as a Complete and Accurate Description and Leads Us to Determine the True Cause of Cancer. "Part-1". CellBio, 7, 1-11.

http://www.scirp.org/journal/cellbio https://doi.org/10.4236/cellbio.2018.71001

[7] Elkhodary, M.S.M. (2018) Quranic Verse No. 8 of Surat Al-Jumu'ah Leads Us to Describe Cancer and Determine Its True Cause (Part-III). CellBio, 6, 35-49. https://doi.org/10.4236/cellbio.2018.73004

[8] Elkhodary, M.S.M. (2018) Quranic Verse No. 8 of Surat Al-Jumu'ah Leads Us to Describe Cancer and Determine Its True Cause (Part-II). CellBio, 6, 13-22. https://doi.org/10.4236/cellbio.2018.82002

[9] Miller, S.E. and Weller, J.M. (1971) Textbook of Clinical Pathology. Williams \& Wilkins, London.

[10] Jain, N.C. and Schalm, O.W. (1986) Veterinary Hematology. 3rd Edition, Lea \& Febiger, Philadelphia, PA.

[11] Drabkin, D.L. (1949) A Simplified Technique for a Large Scale Crystallization of Human Oxyhemoglobin; Isomorphous Transformations of Hemoglobin and Myoglobin in the Crystalline State. Archives of Biochemistry, 21, 224-232.

[12] Murray, R. (1989) Alanine Aminotransferase. Clinical Chemistry, 895-898.

[13] Kaplan, A. (1984) Urea. Clinical Chemistry, 1257-1260.

[14] Murray, R. (1984) Creatinine. Clinical Chemistry, 1247-1243.

[15] Bancroft, G., Stevens, A. and Turner, D. (1996) Theory and Practice of Technique. Livingston, Churchill. 
[16] Hassan, W.A., Yoshida, R., Kudoh, S., et al. (2014) Notch1 Controls Cell Invasion and Metastasis in Small Cell Lung Carcinoma Cell Lines. Lung Cancer, 86, 304-310. https://doi.org/10.1016/j.lungcan.2014.10.007

[17] Hirsch, F.R., Varella-Garcia, M., Bunn Jr., P.A., et al. (2003) Epidermal Growth Factor Receptor in Non-Small-Cell Lung Carcinomas: Correlation between Gene Copy Number and Protein Expression and Impact on Prognosis. Journal of Clinical Oncology, 21, 3798-3807. https://doi.org/10.1200/jco.2003.11.069

[18] Jakoby, W.B. and Ziegler, D.M. (1990) The Enzymes of Detoxification. The Journal of Biological Chemistry, 256, 20715-20718.

[19] Motohashi, H. and Yamamoto, M. (2004) Nrf2-Keap1 Defines a Physiologically Important Stress Response Mechanism. Trends in Molecular Medicine, 10, 549-557. https://doi.org/10.1016/j.molmed.2004.09.003

[20] Jung, K.A. and Kwak, M.K. (2010) The Nrf2 System as a Potential Target for the Development of Indirect Antioxidants. Molecules, 15, 7266-7291. https://doi.org/10.3390/molecules 15107266

[21] Dinkova-Kostova, A.T., Holtzclaw, W.D., Cole, R.N., et al. (2002) Direct Evidence That Sulfhydryl Groups of Keap1 Are the Sensors Regulating Induction of Phase 2 Enzymes That Protect against Carcinogens and Oxidants. Proceedings of the National Academy of Sciences of the United States of America, 99, 11908-11913. https://doi.org/10.1073/pnas.172398899

[22] Keppler, D. (2011) Multidrug Resistance Proteins (MRPs, ABCCs) Importance for Pathophysiology and Drug Therapy. Handbook of Experimental Pharmacology, 201, 299-323. https://doi.org/10.1007/978-3-642-14541-4 8

[23] Mizuno, N., Yotsumoto, T. and Sugiyama, Y. (2003) Impact of Drug Transporter Studies on Drug Discovery and Development. Pharmacological Reviews, 55, 425-461. https://doi.org/10.1124/pr.55.3.1

[24] Veeriah, S., Miene, C., Habermann, N., et al. (2008) Apple Polyphenols Modulate Expression of Selected Genes Related to Toxicological Defence and Stress Response in Human Colon Adenoma Cells. International Journal of Cancer, 122, 2647-2655. https://doi.org/10.1002/ijc.23440

[25] Redlich, G., Zanger, U.M., Riedmaier, S., et al. (2008) Distinction between Human Cytochrome P450 (CYP) Isoforms and Identification of New Phosphorylation Sites by Mass Spectrometry. Journal of Proteome Research, 7, 4678-4688. https://doi.org/10.1021/pr800231w

[26] Yang, C.S., Smith, T.J. and Hong, J.-Y. (1994) Cytochrome P-450 Enzymes as Targets for Chemoprevention against Chemical Carcinogenesis and Toxicity: Opportunities and Limitations. Cancer Research, 54, 1982s-1986s.

[27] Gonzalez, F.J. and Tukey, R.H. (2006) Drug Metabolism. In: Runtonll, B., Lazo, J.S. and Parker, K.L., Eds., Goodman and Gilman's the Pharmacological Basis of Therapeutics, 11th Edition, McGraw Hill, New York, 71-91.

[28] Fuhr, U., Klittich, K. and Staib, A.H. (1993) Inhibitory Effect of Grapefruit Juice and Its Bitter Principle, Naringenin, on CYP1A2 Dependent Metabolism of Caffeine in Man. British Journal of Clinical Pharmacology, 35, 431-436. https://doi.org/10.1111/j.1365-2125.1993.tb04162.x

[29] Kokogule, E., Belce, A., Ozyurt, E. and Tepeler, Z. (1990) Xanthine Oxidase Levels in Human Brain Tumors. Cancer Letters, 50, 179-181. https://doi.org/10.1016/0304-3835(90)90262-V

[30] Sarnesto, A., Linder, K.O. and Raivio, K.O. (1996) Organ Distribution and Molecu- 
lar Forms of Human Xanthine Dehydrogenase/Xanthine Oxidase Protein. Laboratory Investigation, 74, 48-56.

[31] Lin, S., Zhang, G., Liao, Y., Pan, J. and Gong, D. (2015) Dietary Flavonoids as Xanthine Inhibitors: Structure Affinity and Structure-Activity Relationships. Journal of Agricultural and Food Chemistry, 63, 7784-7794. https://doi.org/10.1021/acs.jafc.5b03386

[32] Toninello, A., Pietrangeli, P., De Marchiu, U., Salvi, M. and Mondovi, B. (2006) Amino-Oxidase in Apoptosis and Cancer. Biochimica et Biophysica Acta, 1765, 1-13. https://doi.org/10.1016/j.bbcan.2005.09.001

[33] Shin, J.C. and Chenk, K. (2004) Regulation of MAO-A and MAO-B Gene Expression. Current Medicinal Chemistry, 11, 1995-2005. https://doi.org/10.2174/0929867043364757

[34] Wallace, H.M., Duthie, J., Evans, D.M., Lamond, S., Nicoll, K.M. and Heys, S.D. (2000) Alteration in Polyamine Catabolic Enzymes in Human Breast Cancer Tissue. Clinical Cancer Research, 6, 3657-3661.

[35] Wong, T.S., Chan, W.S., Li, C.H., Man, L.W., Tang, W.Y., Tsao, S.W., Tsang, K.Y., Ho, W.K. and Chan, Y.W. (2010) Curcumin Alters the Migratory Phenotype of Nasopharyngeal Carcinoma Cells through up-Regulation of E-Cadherin. International Institute of Anticancer Research, 30, 2851-2856.25.

[36] Song, X.Q., Zhang, M., Dai, E.Q. and Luo, Y. (2018) Molecular Targets of Curcumin in Breast Cancer. Molecular Medicine Reports, 23-29. https://doi.org/10.3892/mmr.2018.9665

[37] Lui, T., Stern, A. and Robert, L.J. (1999) The Isoprostanes: Novel Prostaglandin-Like Products of the Free Radical Catalyzed Peroxidation of Arachidonic Acid. Journal of Biomedical Science, 6, 226-235. https://doi.org/10.1007/BF02253564

[38] Biaglow, J.E., Mitcgell, J.B. and Held, K. (1992) The Importance of Peroxide and Superoxide in X-Ray Response. International Journal of Radiation Oncology, Biology, Physics, 22, 665-669. https://doi.org/10.1016/0360-3016(92)90499-8

[39] Sayre, L.M., Smith, M.A. and Perry, G. (2001) Chemistry and Biochemistry of Oxidative Stress in Neurodegenerative Disease. Current Medicinal Chemistry, 8, 721-738. https://doi.org/10.2174/0929867013372922

[40] Han, S., Li, Y.Y. and Chan, B.P. (2015) Protease Inhibitors Enhance Extracellular Collagen Fibril Deposition in Human Mesenchyme Stem Cells. Stem Cell Research \& Therapy, 6, 197. https://doi.org/10.1186/s13287-015-0191-1

[41] Donato, L.J. and Noy, N. (2005) Suppression of Mammary Carcinoma Growth by Retinoic Acid: Proapoptotic Genes Are Targets for Retinoic Acid Receptor and Cellular Retinoic Acid Binding Protein II Signaling. Cancer Research, 65, 8193-8199. https://doi.org/10.1158/0008-5472.CAN-05-1177

[42] Birben, E., Sahiner, U.M., Sackesen, C., Erzurum, S. and Kalayci, O. (2012) Oxidative Stress and Antioxidant Defence. World Allergy Organization Journal, 5, 9-19. https://doi.org/10.1097/WOX.0b013e3182439613

[43] Soonlae, R., Chul, J.Y. and Hwa, C.J. (2005) Effects of Vitamin E on Phospholipase A2 Activity and Oxidative Damage to the Liver in Streptozotocin-Induced Diabetic Rats. Annals of Nutrition and Metabolism, 49, 392-396. https://doi.org/10.1159/000088930

[44] Sheng, Y., Abreu, I.A., Cabelli, D.E., Maroney, M.J., Miller, A., Teixeiera, M. and Valentine, J.S. (2014) Superoxide Dismutases and Superoxide Reductases. Chemical Reviews, 114, 3854-3918. https://doi.org/10.1021/cr4005296 
[45] Elgawish, R.A.R. and Abdelrazek, H.M.A. (2014) Effects of Lead Acetate on Testicular Function and Caspase-3 Expression with Respect to Protective Effect of Cinnamon in Albino Rats. Toxicology Reports, 1, 795-801. https://doi.org/10.1016/j.toxrep.2014.10.010

[46] Irshad, M. and Chaudhuri, P.S. (2002) Oxidant-Antioxidant System: Role and Significance in Human Body. Indian Journal of Experimental Biology, 40, 1233-1239.

[47] Schreck, R., Rieber, P. and Baeuerl, P.A. (1991) Reactive Oxygen Intermediates as Apparently Widely Used Messengers in the Activation of the NF-kappa B Transcription Factor and HIV-1. The EMBO Journal, 10, 2247-2258. https://doi.org/10.1002/j.1460-2075.1991.tb07761.x

[48] Kim, H., Seo, J.Y., Roh, K.H., Lim, J.W. and Kim, K.H. (2000) Suppression of NF-kappa B Activation and Cytokine Production by $N$-Acetylcysteiene in Pancreatic Acinar Cells. Free Radical Biology \& Medicine, 29, 674-683. https://doi.org/10.1016/S0891-5849(00)00368-3

[49] Jung, Y., Kim, H., Min, S.H., Rhee, S.G. and Jeong, W. (2008) Dynein Light Chain LC8 Negatively Regulates NF-kb through the Redox-Dependent Interaction with IKB- $\alpha$. The Journal of Biological Chemistry, 283, 23863-23871. https://doi.org/10.1074/jbc.M803072200

[50] Yamamoto, Y. and Gaynor, R.B. (2001) Therapeutic Potential of Inhibition of $\mathrm{NF}-\mathrm{Kb}$ Pathway in the Treatment of Inflammation and Cancer. The Journal of Clinical Investigation, 107, 135-142.

[51] Yin, M.J., Yamamoto, Y. and Gaynor, R.B. (1998) The Anti-Inflammatory Agent Aspirin and Salicylate Inhibitor the Activity of IkB Kinase- $\beta$. Nature, 396, 77-80. https://doi.org/10.1038/23948

[52] Rodgers G.M., Gilreath, J.A., Achebe, M.M., Alwan, L., Arcasoy, M., Ali Beth, S., et al. (2017) NCCN. Cancer- and Chemotherapy-Induced Anemia, Version 2.2017. http://www.nccn.org/professionals/physician gls/pdf/anemia.pdf

[53] Madeddu, C., Gramignano, G., Astara, G., Demontis, R., Sanna, E., Atzeni, V. and Macciò, A. (2018) Pathogenesis and Treatment Options of Cancer Related Anemia: Perspective for a Targeted Mechanism-Based Approach. Frontiers in Physiology, 9, 1294. https://doi.org/10.3389/fphys.2018.01294

[54] Adamson, J.W. (2008) The Anemia of Inflammation/Malignancy: Mechanisms and Management. Hematology, ASH Education Program, 159-165. https://doi.org/10.1182/asheducation-2008.1.159

[55] Jeremiah Say (2015) Come Joy 8Amazing Health Benefit of Blackberries. Reasons Why Blackberries Are Extremely Good for You and Your Health. https://www.servingjoy/

[56] (2019) Health. https://www.healthline.com

[57] Post (2016) Diet to Improve Haemoglobin Level (Hb\%)Practo. https://www.practo.com

[58] Food to Eat Increase Red Blood Cells. https://www.livestrong.com/

[59] Bower, J.E., Ganz, P.A., Irwin, M.R., Arevalo, J.M.G. and Cole, S.W. (2011) Fatigue and Gene Expression in Human Leukocytes: Increased NF- $\kappa$ B and Decreased Glucocorticoid Signaling in Breast Cancer Survivors with Persistent Fatigue. Brain, Behavior, and Immunity, 25, 147-150. https://doi.org/10.1016/j.bbi.2010.09.010

[60] Sudha, M. and Rajkuman, D. (2015) Effect of Glutathione on Hematological Parameter in Isoproteron Induced Myocardial Infarction in Rats. International Journal of Pure \& Applied Bioscience, 3, 267-270. 
[61] Falanga, A., Ofosu, F.A., Delaini, F., et al. (1994) The Hypercoagulable State in Cancer Patients: Evidence for Impaired Thrombin Inhibition. Blood Coagulation \& Fibrinolysis, 5, s19-s23. https://doi.org/10.1097/00001721-199401000-00004

[62] Nash, G.F., Turner, L.F., Scully, M.F. and Kakkar, A.K. (2002) Platelets and Cancer. The Lancet Oncology, 3, 425-430. https://doi.org/10.1016/S1470-2045(02)00789-1

[63] Tranexamic Acid. (2019) https://en.m.wikipedia.orgtransamine-wilipedia/

[64] EM Consult (2015) Lab Test: Aspertate Aminotransferase. AST Level. http://www.embconsult.com/

[65] Delicate, N.P., Delicate, J. and Delicate, L.-A. (2018) Strenuous Exercise-An Unusual Cause of Deranged Liver Enzymes. Case Reports in Clinical Medicine, 7, 177-181. 